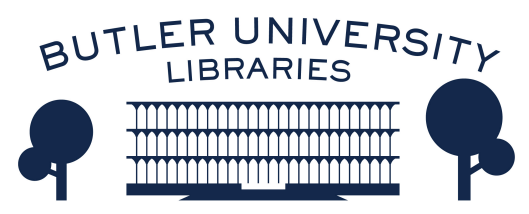

Journal of Hindu-Christian Studies

Volume 26

Article 11

November 2013

\title{
Inter-Religious Contexts and Comparative Theology in the Thought of Evelyn Underhill: Symbolic Narratives of Mysticism and the Songs of Kabìr
}

Michael Stoeber

Regis College/University of Toronto

Follow this and additional works at: https://digitalcommons.butler.edu/jhcs

Part of the Religion Commons

\section{Recommended Citation}

Stoeber, Michael (2013) "Inter-Religious Contexts and Comparative Theology in the Thought of Evelyn Underhill: Symbolic Narratives of Mysticism and the Songs of Kabīr," Journal of Hindu-Christian Studies: Vol. 26, Article 11.

Available at: https://doi.org/10.7825/2164-6279.1550

The Journal of Hindu-Christian Studies is a publication of the Society for Hindu-Christian Studies. The digital version is made available by Digital Commons @ Butler University. For questions about the Journal or the Society, please contact cbauman@butler.edu. For more information about Digital Commons @ Butler University, please contact digitalscholarship@butler.edu. 


\section{Inter-Religious Contexts and Comparative Theology in the Thought of Evelyn Underhill: Symbolic Narratives of Mysticism and the Songs of Kabīr ${ }^{1}$ Michael Stoeber Regis College/University of Toronto}

Introductory Reflections

Evelyn Underhill (1875-1941) regards mysticism as the core of religion. All religions include various dimensions: scripture/ mythology, doctrine/ philosophy, ethics/ law, social/institutional features, ritual, material aspects, and personal and communal experience. ${ }^{2}$ For Underhill, personal religious experience inspires and influences the development of these other aspects of religion-the heart of which is mysticism. Underhill asserts: "The mystics are the pioneers of the spiritual world"3 (4); "Mysticism is the art of union with Reality".
In defining mystics and mysticism generally in this way, Underhill suggests a number of interesting things that pertain to inter-faith conversations. ${ }^{5}$ As pioneers, mystics are regarded as creative originators and innovators of spiritual paths. Mysticism understood as an art suggests a kind of creative and intuitive openness, rather than a rigidly structured orientation and discipline that one finds in the hard sciences, for example. Still, art involves specific skills and practices, and so there are various mystical methods and activities among and between traditions, and the sense of learning and development.

Michael Stoeber is professor of spirituality and philosophy of religion at Regis College and crossappointed to the Department for the Study of Religion, University of Toronto. His main areas of teaching and writing are the nature of religious experience, issues in comparative mysticism, and problems of evil and suffering. In his current research, he is exploring themes in Kundalini Yoga, mysticism in The Brothers Karamazov, and the intersection of spirituality and art. Recent essay publications include: "Mysticism in Ecumenical Dialogue: Questions on the Nature and Effects of Mystical Experience”, Teaching Mysticism, William Parsons, ed. (Oxford University Press, 2011) pp. 224245; "3HO Kundalini Yoga and Sikh Dharma", Sikh Formations, Vol. 8, No. 3 (2012) pp. 351-368; "ReImagining Theosophy Through Canadian Art: Indian Theosophical Influences on the Painting and Writing of Lawren Harris", in Re-imagining South Asian Religions: Essays in Honour of Professors Harold G. Coward and Ronald W. Neufeldt, Pashaura Singh and Michael Hawley, eds. (Leiden: Brill 2013) pp. 195-220; and "Tantra and Śāktism in the Spirituality of Aurobindo Ghose", in Situating Aurobindo: A Reader, Peter Heehs, ed. (New Delhi: Oxford University Press, 2013), pp. 253-86. 
Moreover, art involves teachers: and crossculturally one finds elders, gurus, spiritual directors, masters, guides, and exemplars of the mystical path and ideal, people who help the aspiring mystic find her or his way in the discipline of mystical practice.

Underhill suggests that this definition of mysticism might apply beyond Christian and even theistic religious contexts, by referring to the "object" of mystical experience as "Reality". A mystic becomes aware in an altered state of consciousness of a Reality that is much greater and radically different than one's normal egoic-self. She refers to this awareness as a "union", which could mean a rather loose relation or fellowship that might include a wide variety of spiritual experiences or it might refer to a very radical intimacy-a "junction" or "coalition" or even a "unity"between the subject and the Reality. There is much ambiguity in such a general definition of mysticism. However, notice how these views about mystics and mysticism are an invitation to inter-faith conversation. They suggest that mystics in all authentic religious traditions are the originators and innovators of their traditions and share in a more direct and immediate experience of a common Source. Mystics are intrepid explorers of spiritual frontiers. They provide maps that they draw from their first hand experiences of ultimate Reality, which can assist people in their own transformative movement towards this redemptive or liberating union. Such were Evelyn Underhill's original and provocative claims in the early $20^{\text {th }}$ century.

These claims about mystics and mysticism make Underhill one of the first modern mystical "perennialists", having identified, illustrated, and categorized common core mystical experiences across historical cultures and religious traditions some fifty years before the work of significant scholars of the 1950s and 1960s, such as Frithjof Schuon, Aldous Huxley, W. T. Stace, and Ninian Smart. These folks-dubbed "essentialist" theorists of mysticism-claim there to be a fundamental center of all genuine mysticism that scholars can discern in their close examination of various mystical descriptions and theology across different traditions, cultures, and time periods. ${ }^{6}$ More than this, Underhill in her approach to comparative studies also seems to be somewhat of a forerunner of what more recently has been called "new comparative theology".

Central guidelines of this method of comparative study include: a critical conscious awareness and acknowledgement by theologians of their own faith commitment and biases in comparative analysis; creative, engaged reflection on particular aspects of theological belief or practice of a tradition in comparison with those of one's own; and subsequent creative clarification, elaboration, and rethinking of specific aspects of one's own faith perspective in light of such comparative study ("extended signification"). ${ }^{7}$ As I will illustrate in this paper, Underhill's detailed reflections on specific aspects of non-Christian traditions involved a form of active engagement that vividly supported her development of mystical symbolic narratives and enriched and advanced the christian perspective to which she was normatively committed and participated in.

However, in response to concerns about foundationalist models of comparative religion grounded in presuppositions and agendas that have been biased by modern liberalism, some 
new comparative theologians question positions which regard the concept of "religion" as "a universal category of experience" and they tend to avoid any theorizing related to meta-perspectives about religions. $^{8}$ So, one significant characteristic of Underhill's view that differs from that of some new comparative theologians would seem to be her essentialist perspective on mysticism. New comparative theologians typically remain neutral (or critical) about claims concerning issues of religious or theological pluralism, though it remains unclear to me why such neutrality (or criticism) should be a requirement of their methodology. ${ }^{9}$

This essay illustrates significant aspects of Underhill's pioneering inter-religious and comparative theological context. In exploring the history and dynamics of mysticism, Underhill focused on well over one hundred Christian mystics in her many books and articles. In developing her point of view, she also draws on mystics and ideas from Islam, Judaism, Hinduism, Sikhism, and Buddhism, albeit relatively briefly and mainly in her early writings. In this essay I will focus on comparative reflections she develops in her classic work Mysticism (1910), from her books of poetry $(1912,1916)$, and from introductions she did for the autobiography of Maharshi Devendranath Tagore (1914) and especially for a book on the poetry of Kabir (1915).

\section{Underhill's Three Symbolic Narratives of Mystical Theology}

Underhill argues that mystics are able to transcend the typical mediums of religious experience of normal folk, in a direct "apprehension" of what she calls "Divine Substance". The experienced ultimate Reality, even between very different traditions, has common features: she says it is "always the same Beatific Vision of a Goodness, Truth, and Beauty which is one", even though we find diverse accounts of the experience. Underhill observes:

Attempts...to limit mystical truth-the direct apprehension of the Dvine Substance-by the formulae of any one religion, are as futile as the attempt to identify a precious metal with the die that converts it into current coin. The dies which the mystics have used are many. Their peculiarities and excrescences are always interesting and sometimes highly significant. Some give a far sharper, more coherent impression than others. But the gold from which this diverse coinage is struck is always the same precious metal. ...its substance must always be distinguished from the accidents under which we perceive it : for this substance has an absolute, and not a denominational, importance" (96).

So Underhill distinguishes between the "substance" and the "accidents" of divine Reality. The mystic experiences divine Being substantially in a direct, affective embrace and union that transcends her senses, emotions, and mind. Underhill observes in mystical experience a shifting of awareness to an underlying "higher" Self, in intimate union with Spirit. However, the mystic perceives, interprets, and understands the experience accidentally-according to her socio-religious context and personal temperament. So one finds "diverse coinage" between traditions that is always "struck" from the same "gold" (96). She writes: "This experience is the valid part of mysticism, the thing which gives to it its 
unique importance amongst systems of thought, the only source of its knowledge. Everything else is really guessing aided by analogy" (102).

This "guessing aided by analogy" can be quite different between traditions and Underhill does not downplay its significance to the social, spiritual, and religious life of people. ${ }^{10}$ Although mystics encounter aspects of the same spiritual Reality, they end up developing a wide variety of beliefs and practices, given their individual temperament and socio-cultural context. For example, Underhill acknowledges some of the specific practices and beliefs of Indian religions that diverge from Christian views, such as the notion of avatars, speculations about reincarnation, and claims of extreme quietism, monism, the illusoriness of the phenomenal world, and the annihilation of the self. More generally, she recognizes "the classic dangers, heresies and excesses to which the mystical temperament has always been liable" in all traditions. ${ }^{11}$ As we will see, she also clarifies differences between common threads among traditions. But her focus in her comparative writings is always constructive and explicitly framed within her hope of promoting the positive intellectual, moral and spiritual expansion and transformation of individuals and communities.

In that regard, Underhill insightfully notices in her wide range of reading of mystical writings three major symbolic narratives by which mystics across different traditions have tended to imagine and describe their mystical experiences. There are "three principle ways", she writes, "in which [humanity's] spiritual consciousness reacts to the touch of Reality" (126): these are the themes of spiritual pilgrimage, spiritual marriage, and spiritual transmutation or transformation. I will comment on each of these common themesthe specifics of which diverge considerably among different writers-and then propose a fourth that we also find vividly illustrated in Underhill's writings-the theme of divine immanence in nature.

Influential Christian examples of the pilgrimage narrative are John Bunyan's Pilgrim's Progress and St. Bonaventure's Journey of the Mind to God. However, in illustrating this traditional symbolic narrative, Underhill chooses to highlight the $13^{\text {th }}$ century Muslim Sufi poets Azziz bin Mohammed Nafasi (died 1263) and especially Abū Hamīd bin Abū Bakr Ibrāhīm (1145-1221), who is referred to as "Attar of Nishapur. In his story, "The Colloquy of the Birds", "Attar includes three key features of the traveler's journey, including the magnetic call or deep attraction that draws the pilgrim on a long and difficult journey, the devotional context, which brings illuminating knowledge of God, and, mystical elevation, where the pilgrim enters directly into the Divine whom she has finally reached at the end of her journey.

Guided by the lapwing bird, this pilgrimage for 'Attar requires the difficult passing through seven valleys, from which none have returned to tell the actual distance. In this narrative, there are wild animals and robbers obstructing the way, and the mystic must travel extremely light, stripping herself of all earthly possessions in the first valley of the quest. Having avoided those obstacles that block one's path and once sufficiently detached from material cares and social responsibilities, the pilgrim moves in her radical freedom into the valley of illuminative love, then through the valleys of contemplative 
self-knowledge, absorbed detachment, ecstatic vision, and the dark night of the soul. Finally the mystic pilgrim moves through the valley of self-annihilation, what Underhill calls "the supreme degree of union, or theopathetic state, in which the self is utterly merged, "like a fish in the sea' in the ocean of Divine Love" (132).

I will say more about the "theopathetic" ideal below. But notice how Underhill draws on a Sufi perspective in illustrating possible Christian mystical orientations. Indeed, Underhill shifts to Christian examples in illustrating further how in this symbolic narrative God passionately draws the pilgrim to God's-Self, just as fish are drawn naturally to their spawning pools: "'For our natural Will', says Lady Julian, 'is to have God, and the Good will of God is to have us; and we may never cease from longing till we have Him in fullness of joy" (133-134). This idea of the "love chase"-of pursuing and being pursued by God-is a major mystical-pilgrimage theme across traditions, and is even drawn into the imagery of our natural world: “'Earth', [Meister Eckhart] says, 'cannot escape the sky; let it flee up or down, the sky flows into it, and makes it fruitful whether it will or no. So God does to [humanity]. He who will escape Him only runs to His bosom; for all corners are open to Him"” (136).

Notice how the theme of love typically tends at some point to enter deeply into the symbolic of pilgrimage. But it constitutes a major narrative of its own in the form of spiritual marriage. Its most popular grounding is in a Jewish text, The Song of Songs, a passionately sensual poem of romance and courtship that does not even mention God. Nevertheless, numerous Christian mystics have drawn passionately from this imagery of human love in imaging their spiritual relationship with God. The $12^{\text {th }}$ century Richard of St Victor (died 1173) writes of the "steep stairway of love" in terms of four aspects or stages: betrothal-which corresponds with the stage of mystical purgation, courtshipwhich signifies mystical illumination, wedlock-the unitive stage, and finally the fruitfulness of conjugal relations-where the mystic "Bride" becomes "a 'parent' of fresh spiritual life". Richard "saw clearly that the union of the soul with its Source could not be a barren ecstasy" (140). The key in this narrative is the redirecting of erotic passion towards God, which includes sometimes very vivid sexual, pregnancy, and birthing imagery. I should note that Meister Eckhart, who Underhill does not mention in this context, writes even more provocatively than Richard, of giving birth to Christ from this naked immersion in Godheadof the virgin becoming a wife and then of embodying and exuding the very compassion and justice of God, within which she is immersed in this most intimate union with God.

From the Indian traditions, we find a similar love-narrative in some of the poetic reflections that have been traditionally attributed to the great $15^{\text {th }}$ century north Indian mystic poet Kabī (1440-1518), which Underhill explores in her introduction to his poetry, including the themes of the love-chase, intimate union, and its creative effects:

Subtle is the path of love!

Therein there is no asking and no notasking,

There one loses one's self at His feet,

There one is immersed in the joy of seeking: plunged in the deeps of love as the fish in the water. 
The lover is never slow in offering his head for his Lord's service.

Kabir declares the secret of this love. ${ }^{12}$

Here we find fish-imagery similar to that given by 'Attar in his pilgrimage narrative, highlighting the radical intimacy one has in relation to divine Reality-of being immersed in the divine Presence-who is immanent Source of our being. One is called by Kabīr to awaken to this Satguru (divine eternal teacher) at the heart of one's life.

Underhill perceives in Kabīr's writings evidence also of "the true theopathetic state", ${ }^{13}$ mentioned above. This is the state that Madame Guyon has described as a new life in God, where the mystic "no longer lives or works of herself: but God lives, acts and works in her, and this grows little by little till she becomes perfect with God's perfection, is rich with His riches, and loves with His love" (431). I will return to Kabīr's poetry below. But this idea of the theopathetic state brings us directly to the third type of symbolic narrative common to mystical theology, the theme of an inward alteration, "remaking or regeneration" of the person (140).

Such imagery stresses the inner subject of transformation or transmutation, and is influenced in the West by the traditions of Hermeticism and Spiritual Alchemy, where the prime object was to uncover the philosopher's stone-the transformative substance which would convert base metals into gold. In "Christian" Hermeticism, the philosopher's stone is Jesus Christ, who acts to transmute spiritually the mystic, in redeeming and deifying her fallen nature. ${ }^{14}$ Underhill writes: "We have seen that this idea of the New Birth, the remaking or transmutation of the self, clothed in many different symbols, runs through the whole of mysticism and much theology" (140). In Christian mysticism, it is well illustrated in the writings of Jacob Boehme and William Law, and Underhill mentions some parallel symbols in Chinese spirituality (148). I would propose also that in Hindu thought we find this theme especially in Tantra and Kuṇ̂lalinī Yoga, as powerful spiritual energy is understood to be awakened through various rituals and yoga exercises, and drawn to penetrate the subtle energy centers of the person, purifying and transforming those aspects of persons that resist the spiritual life, and awakening them spiritually, emotionally, and physically, to their spiritual core and ideal.

\section{A Fourth Symbolic Narrative: Spirit in Nature}

Underhill herself develops at least one other rich symbolic narrative beyond those of spiritual pilgrimage, marriage, and transmutation, one that is also colored by her inter-faith conversations with non-Christian religious traditions. This is the theme of the presence of spirit in natural life. Here the mystic does not encounter God as transcendent Other (as in the Pilgrimage narrative) or God as lover (as in the Spiritual Marriage narrative) but rather she comes to see and to experience God in nature. This is a major theme of Underhill's first book of poems, titled Immanence, which she published in 1912. From her Christian experience in that period of her life, this spiritual presence in our created world includes angels, saints, our resurrected ancestors, death itself, and above all Eucharistic liturgy, the Holy Spirit and Christ-all of the themes found in the various poems of this book. She also points toward a kind of nature mysticism-where the natural world appears 
transfused by spiritual light and beauty, and the observer of such epiphanies finds herself drawn into that vision, participating with them and in them.

To be sure, in these poems we find the narrative themes of pilgrimage and spiritual marriage quite explicitly. In the poem "Invitatory", for example, Underhill integrates both themes, in imagining Christ calling the reader to rest in his healing and nourishing presence:

Dear Heart, poor wearied one !...

...'Come ! Bride and Pilgrim, rest,

Thy head upon Love's breast,...

...Come! at Love's mystic table break thy fast'. ${ }^{\prime}{ }^{15}$

But in the opening poem titled "Immanence", God also comes "in the little things", He says:

...Amidst the delicate and bladed wheat

That springs triumphant in the furrowed sod.

There do I dwell, in weakness and in power; ;..

...In your strait garden plot I come to flower:

...I come in the little things,

Saith the Lord :...

...In brown bright eyes

That peep from out the brake, I stand confest.

On every nest

Where feathery Patience is content to brood

And leaves her pleasure for the high emprize

of motherhood-

There doth My Godhead rest. ${ }^{16}$

So Underhill images in feminine symbol the divine spirit in nature, portending the important work of contemporary ecotheologians, such as Thomas Berry and Sally McFague, with her admonitions to recognize and apprehend spiritually the sacred in the natural world, a theme also pronounced in some of her early novels and short stories. She also echoes the beautiful imagery of Julian of Norwich, who writes of our sweet "Mother Jesus"-the creative Word-our "Mother sensual", whose unconditional compassion reforms and restores us with supreme and gentle patience. The "Motherhood" of "Godhead", Underhill writes in her poem "Planting-Time", is also the source of creative light and love:

To paint the earth with tulips is a joy,

It is the satisfaction of desire ;

'Tis to employ

God's own creative touch

And from the smouldering world to strike a coloured fire. ${ }^{17}$

Drawing on a provocative interplay of masculine and feminine imagery, Underhill asks us to imagine being with the holy Mystery of Godhead during God's period of fallowed gestation:

God dreams in plants, they say.

Ah, would that I might creep

Within the magic circle of his winter sleep:...

...Rapt from all other thing

The flowery fancies that clamp his dark.

There Life, who cast away

Her crumpled summer dress,

Sets on the loom

The warp-threads of another loveliness

And weaves a mesh of beauty for the spring.

So nature becomes infused by spirit in God's creative action: 
Here, in this garden bed,

Surely the Spirit and the Bride

Are wed: ... ${ }^{18}$

This weaving together of spirit and nature in harmonious and creative unity continues in Underhill's second book of poems published in 1916, Theophanies: A Book of Verses, but it includes significantly the influences of her inter-faith conversations. On the title page, Underhill quotes John Scotus Erigena: "Every visible and invisible creature is a theophany or appearance of God"; and in her little poem Nihil Longe Deo-[Nothing is far from God]-she writes:

As sleeping infants in their dream despair

We range, and grope thy breast :

But wake to find that haven everywhere

And we already blest. ${ }^{19}$

We are already blessed, she insists, and we need to wake up to this truth-that nature is immersed in spirit and exudes and reveals it dynamically to those who become open to its mystic light.

Drawing explicitly on a significant theme of Hindu spirituality, she titles one poem in Theophanies "Lila, The Play of God". This poem is a conversation with God that begins by addressing God's creative play:

What the sport, and what the aim,

Shrouded Player of the Game?

Lord, the magic of thy play,

Ever changing, never still,

It enchants the dreaming heart,

It enslaves the restless will,

Calls it to the player's part"....

... 0 the rush of birds in flight!

O the blazon of the may!

Holy fading of the day,

Mystery of marshes lying
Faint and still beneath the sky, While the solemn clouds go by And their massy shadows creep Grey upon the glistering sheep.

Noble sport and mighty aim, Shrouded Player of the Game. ... ${ }^{20}$

Here Underhill links the theme of spirit in nature directly to God's dynamic play, which is magical, mysterious, awesome, and wonderful. Although she goes on in this three page poem to ask the very hard questions of how suffering and evil might possibly fit into this image, it is clear that Underhill is adapting this theme of the world as creative play of God directly from mystic poetry attributed to Kabīr, who I mentioned above.

According to tradition, Kabīr was a common man, an uneducated weaver, married, father of four children, who appealed to a wide and diverse audience of Hindus, Muslims, and Sikhs, composing exceptional and brilliant poetry in the Hindi vernacular of his time. Today there are over 9 million people in the devotional movement (Kabir Panthis) that was founded some five hundred years ago, and he has been embraced by a wide variety of traditions and movements. ${ }^{21}$ His historical context is difficult to ascertain. As Underhill notes, “Kabir's story is surrounded by contradictory legends, on none of which reliance can be placed". ${ }^{22}$ It seems clear that he criticized aspects of Yogic, Brahmanic, Vaiṣnava, Śākta, and Islamic beliefs and practices of his time, which complicates the discernment about his origins and orientation. John Stratton Hawley notes that Kabir "seems more at home with Hindu ways", though his Muslim name-“a Quranic title of Allah meaning great"-suggests that he was Muslim, 
perhaps part of a recently converted social group. $^{23}$

In 1915, about a year before she published Theophanies, Underhill assisted 1913 Nobel Prize winner Rabindranath Tagore in his English translation of one hundred poems attributed to Kabir that had earlier been translated from Hindi into Bengali script by Kshitimohan Sen, and she wrote the introduction to this volume. $^{24}$ Although some contemporary Kabīr scholars question the authenticity of most of these poems, Charlotte Vaudeville notes that they were "sung by itinerant Sadhus all over Northern India", translated by Tagore "into beautiful English", read widely in the West, and also translated into French and Russian. These popular poems present a form of bhakti that reflects some of the perspectives of Kabirr, and they certainly reflect a traditional view of Kabirr, even if many of them are probably not his creation. ${ }^{25}$ In his afterword of Robert Bly's more recent popular revised version of Tagore's One Hundred Poems of Kabir, Hawley notes the contrast of this western, more intimately devotional, collection with the eastern "Bijak" collection of the "Barnarsi Kabir"-which has become the scripture of the Kabir Panthis-where Kabir in his poems is more irreverent, confrontational, critical, and skeptical of other religious movements and practices of his time ${ }^{26}$ (though this latter thread certainly runs through the Tagore collection as well). In my exposition I will highlight some of the differences between Underhill's reading of Kabī-which reflects developments within traditional understandings and devotional movements of Kabir-from what some more recent scholars claim to be the more historically authentic Kabìr.
In her introduction to Kabīi's poetry, Underhill praised the inter-faith inclusivism of the traditional Kabir-a "great religious reformer" of the $15^{\text {th }}$ century. She writes how, from Kabīr's poetry, "it is impossible to say [if he] was a Brāhman or Sūfī, Vedāntist or Vaishnavite. He is, as he says himself, 'at once the child of Allah and of Rām,", even if he showed a "frank dislike of all institutional religion, all external observance" and of "the tendency to an exclusively anthropomorphic devotion which results from an unrestricted cult of Divine Personality". ${ }^{27}$ Indeed, in her mystical essentialist perspective, Underhill considers Kabì in his poetry to be praising and loving the same spiritual Reality that she addresses in her own Christian context, and similarly calling humanity to mystic union with this Source. Although I think it doubtful that Kabīr himself was essentialist in Underhill's sense, he did seem to claim a core mystical awakening involving a radical unitive devotional surrender to underlying divine Reality of a formless and qualityless nature. As Hawley observes, for Kabīr "God is not an object, but lies closer to us than our acts of language and symbolic organization permit us to view, and closer to life than the limitations of our own brief and flawed existences allow us to comprehend." ${ }^{28}$ So, Kabìr can sing:

All things are created by the $\mathrm{Om} ;^{29}$

The love-form is His body.

$\mathrm{He}$ is without form, without quality, without decay:

Seek thou union with Him ! ${ }^{30}$

It is said by some traditional commentators that Kabir himself fused in inter-faith dialogue Sufi contemplation of the imageless God of Islam, Tantric and Yogic ideas with Hindu devotion to the personal God Viṣnu, who he 
encountered under the guidance of his famous teacher Ramanand. However, some modern scholars question the historical connection to Ramanand and doubt the characterization of his bhakti as essentially Vaiṣnava. Charlotte Vaudeville, for example, notes with Underhill that Kabīr was critical of Hindu devotional practices oriented towards idols, images, and forms of God, and feels that he was much more his own man-"that he never consciously followed any other guidance than that of the interior Master, the divine Satguru, so that his 'faith' or 'confidence' remained apparently supportless,... ." Kabīr was a proponent of a bhakti Yoga focused strictly on the nirguna aspects of divine Reality-beyond all name and form-which he tended to call Ram or Satguru or Hari. Hindus in Northern India regard Kabīr as a liberal Vaiṣnava- "the initiator of nirguni bhakti"32-and contemporary scholars acknowledge Kabīr's inter-religious dependence on the Nāth-panthi form of Yoga and his lively encounters with many other religious traditions. Clearly, the authentic Kabir was involved in some significant form of inter-religious dialogue (which perhaps even reflected some aspects of the methods of new comparative theology), even if he was in many respects spiritually innovative and could be quite critical of other spiritual paths in some of his poetry. ${ }^{33}$

Underhill writes that the traditional Kabir, along with St Augustine, Rumi, and Jan Van Ruysbroeck, had a special synthetic vision of God. They were able to give vivid expression both to "the personal and impersonal, the transcendent and immanent, static and dynamic aspects of the Divine Nature". So:
Kabir ponders and says : "He who has neither caste nor country, who is formless and without quality, fills all space."

The Creator brought into being the Game of Joy: and from the word Om the creation sprang. ... ${ }^{34}$

Underhill notices parallels with the sense of Trinitarian movement we find expressed by some Christian mystics, from the static and eternal Unity of Godhead, into the manifesting and creative Word of the second Person of the Trinity. Coming from her essentialist perspective, she is struck by the apparent correspondences in vision and description, but goes on to note the subtle shifts in Kabīr's Indian sensibility. For Kabīr-or at least for Kabīr as he has been traditionally understood and read-this formless and unconditioned Being enters into creative play, bringing form out of its own nothingness, as God magically and mysteriously manifests creative life from inert emptiness, beginning with the sacred vibratory $0 m$. The most significant characteristics of this manifestation are joy and play, which go together, hand in hand: "... The Creator brought into being this Game of Joy...", writes Kabìr:

...The earth is His joy; His joy is the sky ;

His joy is the flashing of the sun and the moon;

His joy is the beginning, the middle, and the end ;

His joy is eyes, darkness, and light.

Oceans and waves are His joy : His joy the Sarasvati, the Jumna, and the Ganges.

The Guru is One $:^{35}$ and life and death, union and separation, are all His plays of joy!

His play the land and water, the whole universe! 
His play the earth and the sky!

In play is the Creation spread out, in play it is established. The whole world, says Kabir, rests in His play, yet still the Player remains unknown. ${ }^{36}$

Underhill included this last line as the introduction of her poem that I mentioned above, "Lila, The Play of God": "The whole world, says Kabir, rests in His play, yet still the Player remains unknown". ${ }^{37}$ God as Player is not an object of our senses and intellect but He is omnipresent in His creation-underlying and immanent in His creative play and joy"Hidden within the blade of grass, is the Mountain of Rām"-as he sings in a Sākhì from another collection. ${ }^{38}$ Creative immanence is a major theme of the traditional poetry of Kabir, and it begins with divine play, which Kabīr images as a kind of apophatic dancer whose mysterious movement stimulates the world to life:

...He is pure and indestructible,

His form is infinite and fathomless,

$\mathrm{He}$ dances in rapture, and waves of form arise from His dance.

The body and mind cannot contain themselves, when they are touched by His great joy.

He is immersed in all consciousness, all joys, and all sorrows;

He has no beginning and no end ;

He holds all within His bliss. ${ }^{39}$

Underhill is fascinated by this sensuous imagery of dance to which Kabir loves to refer, and one gets the sense she wants her Christian readers to appreciate deeply the possible devotional dynamics. Although he acknowledges aspects of God that are static and absolute unity, Underhill notes that for Kabirat least for the traditional Kabir-God in relation to nature "is essentially dynamic. It is by the symbols of motion that he most often tries to convey it to us : as in his constant reference to dancing, or the strangely modern picture of that Eternal Swing of the Universe, which is "held by the cords of love". ${ }^{40}$ Kabir in these songs admonishes his readers to open to the cosmic rhythms of creative life, to learn to dance with God, to follow God's lead in entering into the ecstatic joy of God's divine play:

Dance, my heart! dance to-day with joy.

The strains of love fill the days and the nights with music, and the world is listening to its melodies:

Mad with joy, life and death dance to the rhythm of this music. The hills and the sea and the earth dance. The world of man dances in laughter and tears. .... ${ }^{41}$

of course, dance is associated with music, and so Kabīr claims the natural world moves to the rhythms of God's music-it listens to God's songs: "The hills and the sea and the earth dance" to divine melodies, as "The strains of love fill the days and the nights with the music" of God's divine play. So Underhill observes in relation to Christian mystics: "Everywhere Kabir discerns the 'Unstruck Music of the Infinite'-that celestial melody which the angel played to St. Francis, that ghostly symphony which filled the soul of [Richard] Rolle with ecstatic joy." ${ }^{42}$ In this collection, Kabir makes extensive reference to a divine flute player, which Underhill in her commentary naturally associates with Kṛșna, the human incarnation of the God Vișnu, who manifests in the world as the heroic charioteer-prince, or as an infant and child prankster, or as an enchanting young flute player, especially beloved of the fair milkmaid women. However, in these poems, Kabīr does not mention Kṛṣna, and the divine 
flute player is never actually named, though in other poems in this collection Kabīr does refer devotionally to Brahma, Guru, Ram, and Hari. In this traditional reading of Kabīr, the divine is integrated with his rich sense of spirit immanent in the natural world, and of the significance of sacred sounds in evoking Satguru's mystical presence: "The flute of the Infinite is played without ceasing, and its sound is love":

I hear the melody of His flute, and I cannot contain myself:

The flower blooms, though it is not spring ; and already the bee has received its invitation.

The sky roars and the lightning flashes, the waves arise in my heart,

The rain falls; and my heart longs for my Lord.

Where the rhythm of the world rises and falls, thither my heart has reached:

There the hidden banners are fluttering in the air.

Kabir says: "My heart is dying, though it lives." $^{43}$

\section{Concluding Reflections}

I am not sure if Underhill appreciates fully the significance of song for Kabīr as a mystical means that parallels traditional contemplative meditative practices that she develops in her writings. For Kabīr, the practice of vocal mantra meditation would have been a key feature of his devotionalism. Music or sacred sound thus functions in Kabir's theology as much more than symbol of the divine presence in the created world. Its active practice is crucial in the surrender to Satguru and in opening to the awareness of one's essential immersion in Satguru. In line with Kabīr's mystical orientation on this, one contemporary Sikh writer speaks of Shabd Guru-sacred sounds that function as teacher-where meditative chanting might stimulate "a merger between the personal experience of you and the impersonal experience of Infinity beyond you and within you". ${ }^{44}$ I think this factor is what contributes most to the fact that, as Hawley observes, Kabīr "retains a certain bodily focus" in all of his poems, both those traditionally attributed to him and those considered authentic. ${ }^{45}$

Still, Underhill draws on much evocative symbolism from Hindu spirituality to provoke and enrich the spiritual experiences of her Christian readers, in encouraging them to open to the immanent presence of the Holy Spirit in nature in its various forms-including creative play, dance, and music-and its transformative impetus and dynamics. She thus seems to be involved in methods of new comparative theology, in "proceeding by means of limited case studies" ${ }^{46}$ between traditions, which are influencing her understanding and development of Christian spiritual theology. she also portends the creative thought of modern eco-theologians-so crucial for any current Christian theology if it hopes to remain alive and compelling-in stressing the sacredness of the natural world and our potential awareness of spiritual connection with it and dependence on it. Kabir and various other non-Christian mystics also helped her to illustrate these other major symbolic narratives of Christian mysticism-pilgrimage, spiritual marriage, and spiritual transformation. One wonders about the degree to which Underhill's inter-faith conversations continued to inform her later work in Christian spiritual direction and retreats, and in Christian liturgy, as her 
Christian faith matured and deepened. ${ }^{47}$ However, clearly it affected her development of Christian mystical theology in creative and interesting ways. As I said, her understanding of mystics and the mystic life was an invitation to inter-faith conversation, some one hundred years ago now. Indeed, perhaps Underhill's influence was sufficiently far-reaching for us to refer to her as a "grandmother" of both essentialist theories of mysticism and of new comparative theology (or at least of the more significant features thereof), when one takes into account the immense popularity of her writings throughout most of the $20^{\text {th }}$ century.

\section{Notes}

${ }^{1}$ This paper is an extended adaptation of two presentations that I gave at the Evelyn Underhill Association Annual Day of Quiet Reflection at the National Cathedral, Washington, D.C., June 16, 2012. I thank Dana Greene and Kathleen Staudt for the invitation to participate in this event, and for including an earlier draft of this paper in the 2012-2013 Evelyn Underhill Annual Newsletter, "Reflections on the Inter-Faith Conversations of Evelyn Underhill: Symbolic Narratives of Mysticism". Also, my thanks to two anonymous readers of JHCS, and to Ted Ulrich, for helpful suggestions I incorporated into the final draft.

${ }^{2}$ Adapted from Ninian Smart's categories, The World's Religions (Englewood Cliffs, NJ: Prentice Hall, 1989) pp. 9-21.

3 Evelyn Underhill, Mysticism: The Preeminent Study in the Nature and Development of Spiritual Consciousness (New York: Image Book, Doubleday, 1990 [1911]). Hereafter pages from this text are included in brackets in the textbody.

${ }^{4}$ Evelyn Underhill, Practical Mysticism (London:
E.P. Dutton \& Co., Inc., 1914) p. 23. http://dx.doi.org/2027/uc1.32106000203635

5 The following two paragraphs are a close adaptation of reflections I developed in "Mysticism in Ecumenical Dialogue: Questions on the Nature and Effects of Mystical Experience", in Teaching Mysticism, William B. Parsons, ed. (New York: Oxford University Press, 2011) pp. 231-232. http://dx.doi.org/10.1093/acprof:oso/97801997 51198.001 .0001

${ }^{6}$ In more recent scholarship, essentialism has become over-shadowed by "contextualist" theories of mysticism, which tend to focus in their comparative studies on the differences between traditions, in highlighting the way in which socio-religious categories enter into and over-determine the mystical experiences themselves. See, for example, influential anthologies of essays edited by Steven Katz, especially Mysticism and Philosophical Analysis (N.Y.: Oxford Press, 1978) and Mysticism and Religious Traditions (N.Y.: Oxford University Press, 1983). I should note, however that not all contextualists are critical of essentialist perspectives and some influential contextualist perspectives are compatible with and even lean towards a kind of essentialist point of view (e.g. John Hick, An Interpretation of Religion: Human Responses to the Transcendent, $2^{\text {nd }}$ ed. (Basingstoke: Palgrave Macmillan, 2004). Indeed, Kathleen Henderson Staudt outlines certain contextualist features in Underhill's Mysticism ("Rereading Evelyn Underhill's Mysticism", Spiritus, 12 (2012) pp. 113-128. http://dx.doi.org/10.1353/scs.2012.0000). Also, overly narrow or extreme contextualist theories have come under serious criticism. See, for example, Donald Evans, "Can 
Philosophers Limit What Mystics Can Do?", Religious Studies, Vol. 25, No 1 (1989) pp. 53-60. http://dx.doi.org/10.1017/S0034412500019715;

G. William Barnard, "Explaining the Unexplainable: Wayne Proudfoot's Religious Experience", Journal of the American Academy of Religion, Vol. 60, No. 2 (1992) pp. 231-256. http://dx.doi.org/10.1093/jaarel/LX.2.231; and Michael Stoeber, Theo-Monistic Mysticism: A Hindu-Christian Comparison (N.Y.: St Martin's Press, 1994) esp. chs. 1 and 2.

${ }^{7}$ See Francis X. Clooney, Comparative Theology: Deep Learning Across Religious Borders (Malden, MA: Wiley Blackwell, 2010), especially pp. 3-19, where he summarizes the key features of new comparative theology. See also Reid B. Locklin and Hugh Nicholson, "The Return of Comparative Theology", Journal of the American Academy of Religion, Vol. 78, No. 2 (2010) pp. 477514. http://dx.doi.org/10.1093/jaarel/lfq017 They give a substantial survey of the field and related influences, and speak of "extended signification" on p. 493.

8 Locklin and Nicholson, "The Return of Comparative Theology", pp. 478-481. For another substantial overview of these concerns, see also James Fredericks, "A universal religious experience? Comparative theology as an alternative to a theology of religions", Horizons Vol. 22, No. 1 (1995) pp. 67-87.

9 I think that some comparative theologians who criticize essentialist theories of mysticism conflate positions that should be treated separately. It is one thing to suggest that certain socio-cultural trends that followed upon modern liberalism led historically to unquestioned and problematic methodological presuppositions about a universal "religion" and "theology" that now need to be brought to light so that scholars do not continue to misrepresent or mistreat other religious traditions or that of their own. It is quite another to claim that all comparative theologians must cease completely in their studies from considering questions about universalist (or inclusivist or exclusivist) religious truth claims. Underhill is not dogmatically presupposing a religiously mystical essentialism-she thinks that specific theological evidence across some religious traditions supports her point of view and she illustrates and argues this extensively in some of her writings. Moreover, as I will develop in this paper, her analysis of the particularities of other traditions is advancing and enriching her own sense and experience of Christian spirituality-which deepened and widened significantly over her lifetime. Perhaps more importantly, Underhill's essentialist perspective might to some degree actually reflect the truth of the matter. It seems unwise to me to dismiss this possibility at the outset of one's comparative studies, as some recent comparative theologians seem to be doing, because of methodological presuppositions.

10 James Fredericks argues against the essentialist point of view on the grounds that it significantly devalues dimensions of religion other than the common experiential core. Ted Ulrich clarifies Fredericks' concerns: “...the focus on ineffable experience tends to diminish the importance of the particulars of the religions: 'If all religious traditions are in fact different expressions of the same ineffable experience, then the historical specificities of the various religions can be safely overlooked as secondary, if not merely accidental.' If these specificities are not significant, then what is the 
point of comparative study, except to attempt to point out a common, pre-conceptual experience?". Ulrich is quoting Fredericks, “A universal religious experience?", p. 76, in Edward T. Ulrich, "CATHOLIC THEOLOGY, COMPARATIVE STUDY, AND A PRACTICE OF HINDU MEDITATION", at the website for the Dialogue Interreligieux Monastique, at http://www.dimmid.org/index.asp?Type=B_BA SIC\&SEC=\%7B6E8A313C-7CC6-4E72-B33D9B5D42299401\%7D (accessed June 7, 2013).

However, we need to stress here that Underhill obviously regards non-experiential dimensions of religion as very significant; and the point of comparative study for her seems to be primarily to enrich and deepen her own faith-experience and that of her readers, as well as to stimulate, inspire, and inform her readers.

11 Evelyn Underhill, "Introduction", The Autobiography of Maharshi Devendranath Tagore, Satyendranath Tagore and Indira Devi, trs. (London, Macmillan and Co., 1914) pp. xvi-xvii. See also Evelyn Underhill, "Introduction", One Hundred Poems of Kabir, Rabindranath Tagore, tr.,(London: The Macmillan Company, 1915) pp. vi, xxvii-xxx. This book was also published in New York in 1915 by The Macmillan Company titled Songs of Kabir (http://dx.doi.org/2027/uc1.32106013113789).

${ }^{12}$ One Hundred Poems of Kabir, LV, p. 60.

${ }^{13}$ Underhill, "Introduction", One Hundred Poems of Kabir, p. xxi. My italics.

${ }^{14}$ I explore this topic in "Evelyn Underhill on Magic, Sacrament, and Spiritual Transformation," Worship, vol. 77, no. 2 (2003) pp. 132-151.
${ }^{15}$ Evelyn Underhill, Immanence. A Book of Verses (London: J. M. Dent \& Sons Ltd, 1912) pp. 45-46. http://dx.doi.org/2027/uc1.b3342687

${ }^{16}$ Underhill, Immanence, p. 1.

${ }^{17}$ Underhill, Immanence, p. 54.

${ }^{18}$ Underhill, Immanence, pp. 54-55.

${ }^{19}$ Underhill, Immanence, p. 93.

${ }^{20}$ Evelyn Underhill, Theophanies: A Book of Verses (London: J. M. Dent \& Sons, 1916) p. 34. http://dx.doi.org/2027/uc1.b3342686

${ }^{21}$ Charlotte Vaudeville notes: "In Indian religious history, Kabīr is unique: to the Hindus, he is a Vaiṣnava bhakta, to the Muslims a pir, to the Sikhs a bhagat to the sectarian Kabirpanthīs an avatār of the supreme Being; to the modern patriots, Kabir is the champion of Hindu-Muslim unity, to neo-vedāntins a promoter of the Universal Religion... ." Kabir, Vol I (Oxford: Oxford University Press, 1974) p. 3. http://dx.doi.org/2027/mdp.39015004098565 ${ }^{22}$ Underhill, "Introduction”, One Hundred Poems of Kabir, p. x.

${ }^{23}$ John Stratton Hawley, Songs of the Saints of India (N.Y.: Oxford University Press, 2006) p. 36. ${ }^{24}$ The year before, in 1914, Underhill also wrote an introduction to the autobiography of Maharshi Devendranath Tagore (1817-1905), the great $19^{\text {th }}$ century Hindu reformer of the Brahmo Samaj, and the father of Rabindranath. she regarded the senior Tagore as advanced intellectually and spiritually. She wrote: "Those familiar with the history of Christian mystics will find again, in the self-revelations of this modern saint of the East, many of those characteristic experiences and doctrines which are the special joy and beauty of our own tradition of the spiritual life". Evelyn Underhill, "Introduction", The Autobiography of Maharshi Devendranath Tagore, p. $\mathrm{x}$. 
106 Michael Stoeber

${ }^{25}$ Vaudeville, Kabìr, pp. 18, 24.

${ }^{26}$ John Stratton Hawley, "Afterword: Kabir and the Transcendental Bly" in Robert Bly, Kabir: Ecstatic Poems (Boston: Beacon Press, 2004) pp. 81-82.

http://dx.doi.org/2027/mdp.39015058209514

${ }^{27}$ Underhill, "Introduction”, One Hundred Poems of Kabir, pp. viii, ix, xv, xxvii.

${ }^{28}$ Hawley, Songs of the Saints of India, p. 42.

${ }^{29}$ In the Hindu tradition, "Om" is the most sacred syllable and original creative vibration formed within the Divine out of pre-creative emptiness or nothingness.

${ }^{30}$ One Hundred Poems of Kabir, XXVI, pp. 32-33.

${ }^{31}$ Vaudeville, Kabir, p. 119.

${ }^{32}$ Vaudeville, Kabir, pp. 24, 106.

33 Vaudeville notes: "Living in sacred Kāśîi, [Kabir] must have been in constant contact with the holy men of his time, Pandits, Yogīs, Śaiva samnnyāsīs, and Vaiṣnava Bairāgīs, Vīraśaiva Jangamas, Munis and Tapīs-ascetics of every robe and denomination, the motley crowd of saints and sādhus which filled, even more than today, the narrow lanes of the old city. ...This is the confused and somewhat discordant clamour that we hear in his poems". Kabir, pp. 120, 118.

${ }^{34}$ One Hundred Poems of Kabir, pp. xviii, LXXXII, 88.

${ }^{35}$ The "Sarasvati, the Jumna, and the Ganges" are famous rivers of India and thought to possess spiritual power and significance. "Guru" is reference to divine Being as teacher, a term of reference common to Sikhism.

${ }^{36}$ One Hundred Poems of Kabir, LXXXII, pp. 88-89.

${ }^{37}$ Underhill, Theophanies, p. 34.

${ }^{38}$ Vaudeville, Kabir, p. 194.

${ }^{39}$ One Hundred Poems of Kabir, XXVI, p. 33.

${ }^{40}$ Underhill, "Introduction", One Hundred Poems of Kabir, pp. xxxi-xxxii.

${ }^{41}$ One Hundred Poems of Kabir, XXXII, pp. 38-39.

${ }^{42}$ One Hundred Poems of Kabir, p. xxxv.

${ }^{43}$ One Hundred Poems of Kabir, L, pp. 56, LXVIII, pp. 71-72.

${ }^{44}$ Yogi Bhajan and editors, The Aquarian Teacher: KRI International Teacher

Training in Kundalini Yoga as taught by Yogi Bhajan, level 1 instructor textbook, $4^{\text {th }}$ ed., (Santa Cruz, NM: Kundalini Research Institute, 2007) p. 72.

45 Hawley, "Afterword: Kabir and the Transcendental Bly", p. 81.

46 Fredericks "A universal religious experience?", p. 83.

${ }^{47}$ For example, one wonders if Underhill's encounter with the theory and practice of ahimsā in Indian religions at all influenced the pacifist orientation she embraced and espoused during the Second World War. Significant shifts in Underhill's Christian faith-perspective are well illustrated in Evelyn Underhill, Fragments from an Inner Life, Dana Greene, ed. (Harrisburg, PA: Morehouse Publishing, 1993) and in Dana Greene, Evelyn Underhill: Artist of the Infinite Life (New York: Crossroad, 1990). 